\title{
The effect of temperature of the culture medium on the outcome of blood culture
}

\author{
D. G. MODEL AND R. N. PEEL \\ From the Bacteriology Department, St Mary's Hospital, London
}

SYNOPSIS. Small numbers of seven species of bacteria commonly causing bacteraemia in man were inoculated into fresh human blood, and then cultured by a standard method used for diagnostic blood culture. Prior warming of the medium did not improve the recovery of the inoculated bacteria and it is suggested that such warming is not required when performing diagnostic blood culture.

In many hospitals bottles of sterile media used for blood culture are stored and used at room temperature, in other hospitals they are kept in and used direct from a refrigerator, whilst in a few hospitals the medium is warmed to $37^{\circ} \mathrm{C}$ before use. In this paper we report experiments performed to find out whether the result of blood culture is affected by the initial temperature of medium in which blood cultures are made. For this purpose fresh sterile blood was infected with known organisms in such numbers as to resemble blood from patients with bacteraemia. Aliquots of this infected blood were then placed in bottles of blood culture medium at six different initial temperatures and incubated at $37^{\circ} \mathrm{C}$ in the usual way.

\section{Materials and Methods}

The culture medium used throughout the experiments was digest broth with $0 \cdot 1 \%$ glucose, as supplied by Southern Group Laboratories for blood culture.

The organisms used were Salmonella typhi, Escherichia coli, Staphylococcus aureus, Streptococcus viridans, Streptococcus faecalis, Streptococcus pneumoniae, and Neisseria gonorrhoeae. Neisseria gonorrhoeae was used rather than Neisseria meningitidis because it was thought that their growth characteristics were similar and gonococci were more readily available in our laboratory. All the organisms used were isolated originally from clinical material and were considered to be pathogenic. Each species was grown overnight in broth at $37^{\circ} \mathrm{C}$ before inoculation. The number of infective particles in

Received for publication 3 May 1973. each culture were estimated using a previously calibrated EEL nephelometer. Working dilutions of the cultures were then prepared in broth. The streptococci and neisseriae were submitted to light ultrasonification (Electrosonic (H60, PZT) for 15 seconds) to separate pairs and chains so facilitating the nephelometry. Surface viable counts using horse blood agar (Oxoid Columbia agar) were performed to confirm the nephelometry.

Media for the experiments were held for at least three hours before use at each of the following temperatures: $5,20,37,45,56^{\circ} \mathrm{C}$. At each temperature 12 bottles of medium were used, six for controls and six for the definitive investigations.

Two $60 \mathrm{ml}$ amounts of fresh venous blood were taken from one of the authors for each experiment. As soon as the blood had been taken a sufficient amount of the bacterial suspension to give a final concentration of approximately 1 infective particle per $\mathrm{ml}$ was added to the syringe full of blood and mixed by inversion. Four $\mathrm{ml}$ of this infected blood, estimated to contain 4 infective particles, was then added to each of 15 bottles of medium. This procedure was repeated until six blood cultures at each of the different initial temperatures were made. These blood cultures were then incubated immediately at $37^{\circ} \mathrm{C}$ for 24 hours.

At each initial temperature controls were made by adding organisms without blood to six bottles of medium then incubating at $37^{\circ} \mathrm{C}$. The organisms were from working dilutions and the numbers added to each of the bottles in the control experiment were the same as the number added in the definitive experiments in which blood was used, that is, an estimated 4 infective particles. In the control experiment involving the more fastidious organisms, Streptococcus pneumoniae and Neisseria gonorrhoeae, 
it was necessary to add $8 \%$ of sterile horse serum to the culture medium in order to obtain growth.

\section{Results}

\section{CULTURES WITH BLOOD}

The accompanying table of results shows that with the medium initially at 5,20 , and $37^{\circ} \mathrm{C}$ five or six of the six bottles in each of the groups yielded positive results, ie, the bacteria grew as well in an initially cold medium as in the media initially at 20 and $37^{\circ} \mathrm{C}$. At $45^{\circ} \mathrm{C}$ the yield of positive cultures of Neisseria gonorrhoeae was reduced, and at $56^{\circ} \mathrm{C}$ the yield of both Streptococcus pneumoniae and Neisseria gonorrhoeae was reduced.

\section{Controls}

There was a fall in yield of positive cultures of Neisseria gonorrhoeae when the initial temperature of the medium was $20^{\circ} \mathrm{C}$ or above, and a less clearly marked fall in the yield of positive cultures of Staphylococcus aureus and Streptococcus viridans as the initial temperature of the medium increased.

A trend test applied to the results of the Neisseria gonorrhoeae cultures showed that as the initial temperature of the medium was increased the fall in the yield of positive cultures was significant, $\chi_{1}^{2}=17.8152(\mathrm{P}<0.01)$.

\section{Discussion}

It is well known that sudden chilling can cause a loss of viability of organisms such as Escherichia coli (Meynell, 1958) and it is common knowledge that pathogenic neisseria are very sensitive to temperature. No doubt it is for this reason that when making blood cultures before heating of the medium to $37^{\circ} \mathrm{C}$ has been recommended (Stokes, 1968). Nonetheless the results of the present experiments suggest that between 5 and $37^{\circ} \mathrm{C}$ the initial temperature of the culture medium does not effect the outcome of the blood culture. Some organisms such as Staphylococcus aureus appear resistant to cold shock (Gorrill and McNeil, 1960). The length of time that an organism is held at a low temperature is also critical (Strange and Dark, 1962) but there is little loss of viability if after rapid cooling the suspension is immediately warmed. Our findings are in accordance with this observation since nearly all the bottles which had been at $5^{\circ} \mathrm{C}$ yielded organisms after incubation. For this reason we suggest that if blood cultures are made in cold media they should be incubated at once.

Theoretically bacteria which have never previously been grown artificially may be more susceptible to cold shock than those accustomed to artificial media. This point would be conclusively proved if over a period, one extra bottle at $5^{\circ} \mathrm{C}$ was inoculated in parallel with warm medium for routine blood cultures and no difference was observed.

Bottles of medium at temperatures above $37^{\circ} \mathrm{C}$ were included in the experiment because phagocytosis is reduced or inhibited at low temperatures (Brumfitt, Glynn, and Percival, 1965) and probably also at higher temperatures. If rapid heating or cooling of the blood when it was added to the culture medium had a greater lethal effect on the phagocytes than the bacteria then there might be an advantage in using either hot or cold media. This idea was not supported by our results.

Growth did not occur in every bottle to which an inoculation was added. This was probably due to the random nature of the distribution of the organisms in the blood and the broth. It is likely in situations such as this, where very small numbers of organisms are used, that some of the inocula do not contain any organisms. This is probably also true of the clinical situation for which reason more than one blood culture should be made when bacteraemia is suspected.

\begin{tabular}{|c|c|c|c|c|c|c|c|c|c|}
\hline \multicolumn{2}{|c|}{ Temperature $\left({ }^{\circ} \mathrm{C}\right)$} & \multirow{2}{*}{$\begin{array}{l}\text { S. typhi } \\
6 \\
6\end{array}$} & \multirow{2}{*}{$\begin{array}{l}\text { E. coli } \\
6 \\
6\end{array}$} & \multirow{2}{*}{$\begin{array}{l}\text { Str. aureus } \\
5 \\
6\end{array}$} & \multirow{2}{*}{$\begin{array}{l}\text { Str. viridans } \\
6 \\
4\end{array}$} & \multirow{2}{*}{$\begin{array}{l}\text { Str. faecalis } \\
6 \\
6\end{array}$} & \multirow{2}{*}{$\begin{array}{l}\text { Str. pneumoniae } \\
6 \\
6\end{array}$} & \multirow{2}{*}{$\begin{array}{l}\text { N. gonorrhoeae } \\
5 \\
5\end{array}$} & \multirow{2}{*}{$\begin{array}{l}\text { Totals } \\
40 \\
39\end{array}$} \\
\hline 5 & $\begin{array}{l}\text { Test } \\
\text { Control }\end{array}$ & & & & & & & & \\
\hline 20 & $\begin{array}{l}\text { Test } \\
\text { Control }\end{array}$ & $\begin{array}{l}5 \\
6\end{array}$ & $\begin{array}{l}6 \\
6\end{array}$ & $\begin{array}{l}5 \\
3\end{array}$ & $\begin{array}{l}6 \\
6\end{array}$ & $\begin{array}{l}6 \\
6\end{array}$ & $\begin{array}{l}5 \\
5\end{array}$ & $\begin{array}{l}6 \\
3\end{array}$ & $\begin{array}{l}39 \\
35\end{array}$ \\
\hline 37 & $\begin{array}{l}\text { Test } \\
\text { Control }\end{array}$ & $\begin{array}{l}6 \\
6\end{array}$ & $\begin{array}{l}6 \\
6\end{array}$ & $\begin{array}{l}5 \\
5\end{array}$ & $\begin{array}{l}6 \\
6\end{array}$ & $\begin{array}{l}5 \\
6\end{array}$ & $\begin{array}{l}5 \\
6\end{array}$ & $\begin{array}{l}6 \\
2\end{array}$ & $\begin{array}{l}39 \\
37\end{array}$ \\
\hline 45 & $\begin{array}{l}\text { Test } \\
\text { Control }\end{array}$ & $\begin{array}{l}6 \\
6\end{array}$ & $\begin{array}{l}6 \\
6\end{array}$ & $\begin{array}{l}5 \\
3\end{array}$ & $\begin{array}{l}6 \\
5\end{array}$ & $\begin{array}{l}6 \\
6\end{array}$ & $\begin{array}{l}6 \\
6\end{array}$ & $\begin{array}{l}4 \\
2\end{array}$ & $\begin{array}{l}39 \\
34\end{array}$ \\
\hline 56 & $\begin{array}{l}\text { Test } \\
\text { Control }\end{array}$ & $\begin{array}{l}5 \\
6\end{array}$ & $\begin{array}{l}6 \\
6\end{array}$ & $\begin{array}{l}6 \\
3\end{array}$ & $\begin{array}{l}6 \\
4\end{array}$ & $\begin{array}{l}6 \\
6\end{array}$ & $\begin{array}{l}1 \\
6\end{array}$ & $\begin{array}{l}\mathbf{0} \\
\mathbf{0}\end{array}$ & $\begin{array}{l}30 \\
31\end{array}$ \\
\hline
\end{tabular}

Table Number of cultures out of six showing growth after incubation 
We wish to thank Professor R. E. O. Williams and Mrs S. Hunnes for advice and encouragement and Mrs S. Paxton for clerical assistance.

References

Brumfitt, W., Glynn, A. A., and Percival, A. (1965). Factors influ- encing the phagocytosis of Escherichia coli. Brit. J. exp. Path., 46, 215-226.

Gorrill, R. H., and McNeil, E. M. (1960). The effect of cold diluent on the viable count of Pseudomonas pyocyanea.J. gen. Microbiol., 22, 437-442.

Meynell, G. G. (1958). The effect of sudden chilling of Escherichia coli. J. gen. Microbiol., 19, 380-389.

Stokes, E. J. (1968). Clinical Bacteriology, 3rd ed. Arnold, London.

Strange, R. E., and Dark, F. A. (1962). Effect of chilling aerobacter aerogenes in aqueous suspension. J. gen. Microbiol., 29,719-730

\section{The June 1973 Issue}

\section{THE JUNE 1973 ISSUE CONTAINS THE FOLLOWING PAPERS}

Bactericidal activity of metronidazole against Bacteroides fragilis J. P. F. WHELAN AND J. H. HALE

Septicaemia due to Pasteurella pneumotropica BOGUMILA T. ROGERS, J. C. ANDERSON, CYNTHIA A. PALMER, AND W. G. HENDERSON

Isolation of Neisseria lactamicus from the nasopharynX ANGELA H. PYKETT

Bacterial contamination of platelet concentrates stored at $20^{\circ} \mathrm{C}$ MARGARET CUNNINGHAM AND JOHN D. CASH

Speciation and amphotericin B sensitivity studies on blood isolates of Candida from burned patients DONALD D. STIERITZ, EDWARD J. LAW, AND IAN ALAN HOLDER

Anti-gamma haemolysin as a diagnostic test in staphylococcal osteomyelitis A. G. TAYLOR AND M. PLOMMET

Mucinous cystadenoma and cystadenocarcinoma of the vermiform appendix with particular reference to mucocele and pseudomyxoma peritonei N. M. GIBBS

Tuberculoid lymphadenitis due to Mycobacterium chelonei C. A. MORRIS, G. H. GRANT, P. H. EVERALL, AND A. T. M. MYRES

Staining procedures for the endocrine cells of the upper gastrointestinal mucosa: Light-electron microscopic correlation for the gastrin-producing cell SERGIO A. BENCOSME AND JUAN LECHAGO
A comparative survey of the results of analyses of blood serum in clinical chemistry laboratories in the United Kingdom T. P. WHITEHEAD, D. M. BROWNING, AND A. GREGORY

Measurement of methaemalbumin in plasma $\mathbf{K}$. MURRAY, M. KNIGHT, AND J. A. OWEN

\section{Technical methods}

A technique for bacteriological sampling of hair CHRISTINA M. BANNERMAN, W. A. BLACK, AND D. A. BLACK

Comparison of techniques for distinguishing staphylococci and micrococci LUCY BOSSCHER-ZONDERMAN AND INGRID SMITH

Chandler's thrombi as agents for the assessment of antithrombotic drugs in vitro DAVID $H$. LAWSON, MARGARET M. HUTTON, AND GEORGE P. MCNICOL

An automated method for the quantitative assessment of low concentrations of glucose in urine A. M. EMMERSON, P. GARCIA-WEBB, AND SUSAN J. TURNER

An apparatus for the thawing of stored blood in liquid nitrogen R. MITCHELL, W. MUIR, AND E. A. MCLAREN

\section{Letters to the Editor}

Book reviews

Copies are still available and may be obtained from the PUBLISHING MANAGER, BRITISH MEDICAL ASSOCIATION, TAVISTOCK SQUARE, LONDON, WC1H 9JR, price $£ 1.05$ 